\title{
Pengaruh Iklim Komunikasi Organisasi Terhadap Kinerja Pegawai
}

\author{
Melia, H.H. Daniel Tamburian \\ melia.abidin97@gmail.com,danielt@fikom.untar.ac.id \\ Fakultas Ilmu Komunikasi Universitas Tarumanagara
}

\begin{abstract}
This research is aimed to know if there is an impact of organizational communication climate on employee performance at Ernst \& Young Indonesia Assurance Division Retail and Consumer Product Sub-Division. The population of this research is 463 and with the helped of Slovin's Formula, the sample size that we got is 82. This research uses the survey questionnaires which were collected using Random Sampling with Likert Scale. The data that we used in this research is based on the questionnaires and desktop studies. We used validity test, reliability test, and normality test as the analysis test qualification. The analysis method that we use is T test, simple regression linear, correlation coefficient, and determination coefficient. The research found that: (1) There is an impact of organizational communication climate on employee performance at Ernst \& Young Indonesia Assurance Division Retail and Consumer Product Sub-Division. (2) There is an impact of organizational communication climate on employee performance with the $t$ value $=6,646$. There is a signification impact with the signification level $=0,000<0,05$. (3) The Pearson Correlation 0,596 showed that there is an average impact of organizational communication climate on employee performance at Ernst \& Young Indonesia Assurance Division RCP Sub-Division. (4) 35,6 \% of employee performance was affected by the organizational communication climate.
\end{abstract}

Keywords: communication climate, organizational communication, employee performance

\begin{abstract}
Abstrak
Tujuan penelitian ini adalah untuk mengetahui apakah terdapat pengaruh antara iklim komunikasi terhadap kinerja pegawai Ernst \& Young Indonesia divisi Assurance sub-divisi Retail dan Consumer Product. Populasi pada penelitian ini berjumlah 463 orang, dengan menggunakan bantuan rumus Slovin, jumlah sampel didapatkan sebanyak 82 orang. Penelitian ini akan menggunakan survei dengan teknik random sampling dan dihitung dengan skala Likert. Data dalam penelitian ini bersumber dari kuisioner dan studi kepustakaan. Uji persyaratan analisis menggunakan uji validitas, uji normalitas, dan uji reliabilitas. Metode analisis yang digunakan adalah uji $\mathrm{T}$, analisis regresi linear sederhana, koefisien korelasi, serta koefisien determinasi. Hasil penelitian ini menunjukkan bahwa: (1) Terdapat pengaruh antara Iklim Komunikasi Organisasi terhadap Kinerja Pegawai Ernst \& Young Indonesia divisi Assurance sub-divisi Retail and Consumer Product, (2) Terdapat pengaruh yang terjadi antara kedua variabel dengan angka uji $t=6,646$. Pengaruh yang terjadi juga menunjukkan pengaruh yang signifikan dengan jumlah tingkat signifikasi $=0,000<0,05$, (3) Hasil angka korelasi Pearson 0,596 yang menunjukkan bahwa iklim komunikasi organisasi memiliki hubungan yang sedang dengan kinerja pegawai khusunya di Ernst \& Young Indonesia divisi Assurance sub-divisi Retail and Consumer Product, (4) Iklim komunikasi organisasi 35,6\% mempengaruhi kinerja pegawai.
\end{abstract}

Kata kunci: iklim komunikasi, komunikasi organisasi, kinerja pegawai 


\section{Pendahuluan}

Manusia sebagai makhluk sosial perlu berkomunikasi untuk membangun hubungan disertai pertukaran pesan/informasi dalam usaha untuk mencapai tujuan tertentu. Komunikasi yang dilakukan ini melibatkan diri sendiri, antar pribadi, kelompok kecil, kelompok organisasi, dan massa. Kecenderungan manusia untuk berkomunikasi ini terus berlanjut dan dilakukan di lingkungan organisasi ketika mereka sedang bekerja. Para pegawai yang bekerja pada suatu perusahaan memiliki kewajiban untuk berkomunikasi satu sama lain.

Salah satu aspek yang dapat memengaruhi keberhasilan sebuah perusahaan adalah iklim komunikasi yang tercipta di perusahaan tersebut. Perubahan iklim komunikasi yang terjadi pada suatu organisasi dapat mempengaruhi kinerja dan produktivitas karyawan (Pace dan Faules, 2015). Menurut penelitian Ahmad Fauzi (2014), kinerja aparatur di Pemerintahan Desa Situ Udik dapat dipengaruhi oleh iklim komunikasi organisasi sebesar 33,8\%. Dede Irawan (2016) melakukan penelitian dengan hasil yang menunjukkan bahwa iklim komunikasi organisasi sebesar $82,1 \%$ mempengaruhi kinerja pegawai Kantor Keluarga Berencana Jakarta Barat.

Redding (1972) menyatakan bahwa "iklim (komunikasi) organisasi jauh lebih penting daripada keterampilan atau teknik-teknik komunikasi semata-mata dalam menciptakan suatu organisasi yang efektif' (Pace dan Faules, 2015). Iklim komunikasi menjadi unsur penting dalam produktivitas organisasi. Hal ini terjadi karena iklim komunikasi mempengaruhi cara hidup, perilaku dan pengambilan keputusan dari anggota organisasi. Ruben dan Stewart (2013) juga mengungkapkan bahwa penelitian menujukkan bahwa di mana iklim suportif berkembang, dimana kepuasan kerja tinggi begitu produktivitas juga meningkat. Iklim komunikasi memegang peranan sentral dalam meningkatkan kinerja karyawan dalam suatu perusahaan, termasuk di Ernst \& Young Indonesia. Ernst \& Young Indonesia merupakan salah satu perusahaan yang dijuluki sebagai "Big Four", yaitu salah satu dari Kantor Akuntan Publik (KAP) terbesar di Indonesia (http://www.pppk.kemenkeu.go.id/News/Details/18 diakses pada 10 September 2018 pukul 13.25).

Permasalahan yang diangkat yakni apakah terdapat pengaruh antara iklim komunikasi organisasi terhadap kinerja pegawai Ernst \& Young Indonesia Divisi Assurance sub-divisi Retail and Consumer Product? Penelitian ini ingin mengetahui apakah terdapat hubungan antara iklim komunikasi organisasi terhadap kinerja pegawai Ernst \& Young Indonesia divisi Assurance sub-divisi RCP. Hipotesis penelitian awal adalah tidak terdapat pengaruh antara iklim komunikasi organisasi terhadap kinerja pegawai, dan terdapat pengaruh antara iklim komunikasi organisasi terhadap kinerja pegawai.

\section{Metode Penelitian}

Metode penelitin yang digunakan pada penelitian ini adalah metode kuantitatif dengan sifat deskriptif. Menurut Bungin (2005), penelitian deskriptif bertujuan untuk menjelaskan, meringkaskan berbagai kondisi atau berbagai variabel yang timbul di masyarakat yang menjadi objek penelitian itu berdasarkan apa yang terjadi. Teknik pengumpulan data yang digunakan dalam penelitian ini adalah melalui kuisioner dan studi kepustakaan. Populasi pada penelitian ini adalah seluruh pegawai Ernst \& Young Indonesia divisi Assurance sub-divisi RCP yang berjumlah 463 orang. Dengan sampel sebanyak 82 orang yang didapatkan berdasarkan rumus Slovin. 
Skala pengukuran yang digunakan adalah skala likert. Dalam skala likert, variabel yang diukur akan dijabarkan menjadi indikator variabel (Sugiyono, 2011). Dimana skor yang diberikan untuk jawaban skala likert adalah: Sangat Setuju (5), Setuju (4), Netral (3), Tidak Setuju (2), dan Sangat Tidak Setuju (1).

Gambar 1. Kerangka Pemikiran

1. Kepercayaan

2. Pengambilan keputusan

3. Kejujuran

4. Keterbukaan di dalam komunikasi ke bawah

5. Mendengarkan di dalam komunikasi ke atas

6. Perhatian pada tujuan berkinerja tinggi (Pace dan Faules, 2015)
Kinerja Pegawai (Y)

1. Profesional

2. Tanggung jawab

3. Kreatif

4. Berkarakter

5. Kepatuhan

6. Kompetitif (Duha, 2016)

Tabel 1. Operasionalisasi Konsep

\begin{tabular}{|c|c|c|c|}
\hline \multirow{6}{*}{\begin{tabular}{l}
\multicolumn{1}{c}{ Variabel } \\
Iklim \\
Komunikasi \\
Organisasi (X) \\
Iklim \\
komunikasi \\
adalah atmosfer \\
atau nada suara \\
para anggota \\
tentang \\
pengalaman \\
organisasi \\
selama mereka \\
melakukan \\
rutinitas \\
kesehariannya \\
(Ruben dan \\
Stewart, 2013)
\end{tabular}} & $\begin{array}{c}\text { Dimensi } \\
\text { Kepercayaan }\end{array}$ & $\begin{array}{l}\text { Indikator } \\
\text { 1. Kepercayaan pimpinan pada kemampuan } \\
\text { karyawan. } \\
\text { 2. Kepercayaan karyawan pada kredibilitas } \\
\text { pimpinan. }\end{array}$ & $\begin{array}{r}\text { Skala } \\
\text { Likert }\end{array}$ \\
\hline & $\begin{array}{l}\text { Pengambilan } \\
\text { Keputusan }\end{array}$ & $\begin{array}{l}\text { 1. Keterlibatan karyawan dalam } \\
\text { memberikan pendapat mengenai } \\
\text { permasalahan di perusahaan. } \\
\text { 2. Keputusan yang diambil berdasarkan } \\
\text { saran dan masukan dari karyawan. } \\
\end{array}$ & Likert \\
\hline & Kejujuran & $\begin{array}{l}\text { 1. Karyawan bebas untuk mengemukakan } \\
\text { pendapat di hadapan pimpinan. } \\
\text { 2. Pegawai selalu jujur dalam } \\
\text { menyampaikan informasi mengenai } \\
\text { pekerjaannya. }\end{array}$ & Likert \\
\hline & $\begin{array}{l}\text { Keterbukaan } \\
\text { di dalam } \\
\text { komunikasi ke } \\
\text { bawah }\end{array}$ & $\begin{array}{l}\text { 1. Karyawan mudah untuk mendapatkan } \\
\text { informasi dari atasan. } \\
\text { 2. Ketersediaan pemimpin untuk } \\
\text { memberikan bantuan jika terjadi masalah } \\
\text { pada pekerjaan. }\end{array}$ & Likert \\
\hline & $\begin{array}{l}\text { Mendengarka } \\
\mathrm{n} \text { di dalam } \\
\text { komunikasi ke } \\
\text { atas }\end{array}$ & $\begin{array}{l}\text { Ketersediaan pemimpin untuk menerima } \\
\text { kritik. } \\
\text { 2. Ketersediaan pemimpin untuk } \\
\text { mendengarkan keluhan pegawai. } \\
\text { 3. Pemimpin mengganggap informasi dari } \\
\text { bawahan adalah penting }\end{array}$ & Likert \\
\hline & $\begin{array}{l}\text { Perhatian pada } \\
\text { tujuan } \\
\text { berkinerja } \\
\text { tinggi }\end{array}$ & $\begin{array}{l}\text { 1. Pemahaman pegawai terhadap tujuan } \\
\text { perusahaan. } \\
\text { 2. Usaha bersama antara pegawai dan } \\
\text { pimpinan dalam mencapai tujuan } \\
\text { perusahaan. }\end{array}$ & Likert \\
\hline $\begin{array}{l}\text { Kinerja } \\
\text { Pegawai (Y) }\end{array}$ & Profesional & $\begin{array}{l}\text { 1. Kerja keras dalam menyelesaikan } \\
\text { pekerjaan } \\
\text { 2. Pengetahuan akan pekerjaan }\end{array}$ & Likert \\
\hline
\end{tabular}




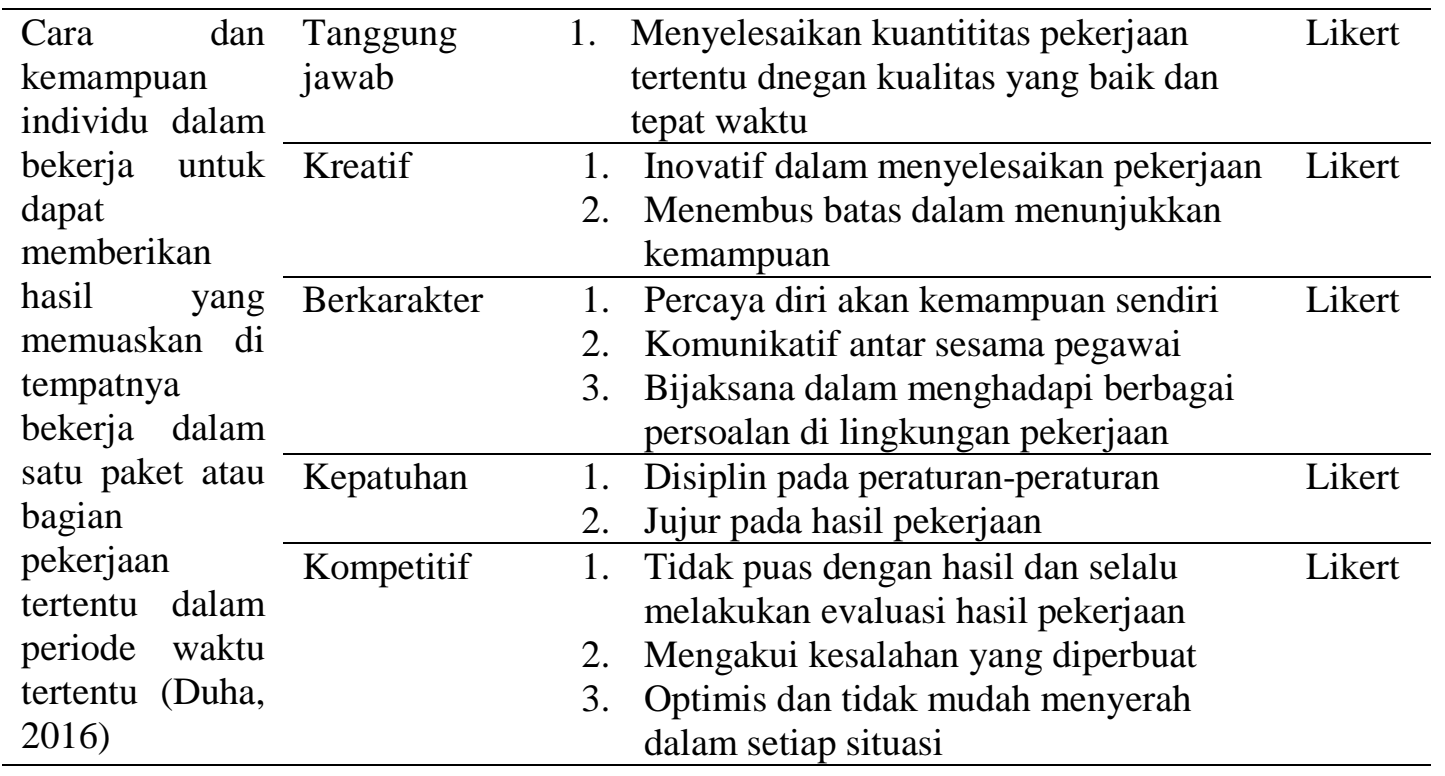

\section{Hasil Temuan dan Diskusi}

Karakteristik responden:

a. Jenis kelamin: Sebanyak $42.7 \%$ responden berjenis kelamin laki-laki dan 57 . $3 \%$ berjenis kelamin perempuan.

b. Usia: Sebanyak $82.9 \%$ responden berusia $<25$ tahun, $15.9 \%$ responden berusia 26-30 tahun, dan $1.2 \%$ responden berusia 31-35 tahun.

c. Status: Sebagian besar responden sebanyak $69.3 \%$ responden belum menikah dan sisanya $3.7 \%$ responden sudah menikah.

d. Pendidikan: Hampir semua responden $97.6 \%$ responden merupakan lulusan S1 dan $2.4 \%$ merupakan lulusan S2.

e. Lama bekerja: Sebanyak $48.8 \%$ responden bekerja selama $\leq 1$ tahun, $43.9 \%$ responden bekerja selama 2-3 tahun, 6.1\% responden bekerja selama 4-6 tahun, dan $1.2 \%$ responden bekerja selama 7-8 tahun.

Uji Validitas

Tabel 2. Variabel Iklim Komunikasi Organisasi

\begin{tabular}{|c|c|c|c|c|}
\hline & $\begin{array}{c}\text { Scale Mean if Item } \\
\text { Deleted }\end{array}$ & $\begin{array}{c}\text { Scale Variance if } \\
\text { Item Deleted }\end{array}$ & $\begin{array}{r}\text { Corrected Item- } \\
\text { Correlation } \\
\end{array}$ & $\begin{array}{l}1 \text { Cronbach's Alpha if } \\
\text { Item Deleted }\end{array}$ \\
\hline $\mathrm{X} 1$ & 39.7927 & 11.080 & .298 & .625 \\
\hline $\mathrm{X} 2$ & 39.7317 & 11.310 & .278 & .628 \\
\hline $\mathrm{X} 3$ & 39.5976 & 11.231 & .356 & .617 \\
\hline $\mathrm{X} 4$ & 39.7195 & 10.846 & .380 & .610 \\
\hline $\mathrm{X} 5$ & 39.6220 & 11.670 & .260 & .632 \\
\hline X6 & 39.4878 & 11.315 & .333 & .620 \\
\hline $\mathrm{X} 7$ & 39.7805 & 10.692 & .408 & .605 \\
\hline X8 & 39.9634 & 10.850 & .268 & .632 \\
\hline X9 & 40.4878 & 11.265 & .232 & .638 \\
\hline X10 & 39.5366 & 11.388 & .245 & .634 \\
\hline X11 & 39.6951 & 11.474 & .220 & .639 \\
\hline $\mathrm{X} 12$ & 39.7439 & 11.181 & .234 & .638 \\
\hline
\end{tabular}

Sumber: Hasil Pengolahan Data SPSS Versi 25.0 
Tabel 3. Variabel Kinerja Pegawai

\begin{tabular}{|c|c|c|c|c|}
\hline & $\begin{array}{c}\text { Scale Mean if Item } \\
\text { Deleted }\end{array}$ & $\begin{array}{l}\text { Scale Variance if } \\
\text { Item Deleted }\end{array}$ & $\begin{array}{c}\text { Corrected Item-Total } \\
\text { Correlation }\end{array}$ & $\begin{array}{l}\text { Cronbach's Alpha if } \\
\text { Item Deleted }\end{array}$ \\
\hline Y1 & 45.6341 & 16.902 & .435 & .770 \\
\hline $\mathrm{Y} 2$ & 45.8415 & 17.567 & .351 & .777 \\
\hline Y3 & 46.2073 & 16.463 & .404 & .774 \\
\hline Y4 & 45.8049 & 18.110 & .281 & .783 \\
\hline Y5 & 45.8049 & 16.924 & .428 & .771 \\
\hline Y6 & 45.7317 & 16.495 & .494 & .764 \\
\hline Y7 & 45.9268 & 16.538 & .523 & .762 \\
\hline Y8 & 45.8171 & 16.695 & .469 & .767 \\
\hline Y9 & 45.7439 & 16.662 & .424 & .771 \\
\hline Y10 & 45.6829 & 17.034 & .354 & .778 \\
\hline Y11 & 45.7439 & 17.131 & .396 & .774 \\
\hline Y12 & 45.6341 & 17.593 & .406 & .773 \\
\hline Y13 & 45.4512 & 17.189 & .414 & .772 \\
\hline
\end{tabular}

Sumber: Hasil Pengolahan Data SPSS Versi 25.0

Berdasarkan hasil-hasil perhitungan di atas, dapat disimpulkan bahwa sebanyak dua belas butir pernyataan dalam variabel (X) "Iklim Komunikasi Organisasi" dan tiga belas butir pernyataan dalam variabel (Y) "Kinerja Pegawai" memiliki nilai $r$ hitung > 0,200 , yang berarti semua pernyataan pada $\mathrm{X}$ dan $\mathrm{Y}$ telah valid.

Uji Reliabilitas

Tabel 4. Reliabilitas Variabel Iklim Komunikasi Organisasi

\begin{tabular}{ll}
\hline Cronbach's Alpha $\quad$ N of Items \\
$\frac{.647}{\text { Sumber: Pengolahan Data SPSS Versi } 25.0}$
\end{tabular}

Dari pengujian reliabilitas terhadap 12 butir variabel iklim komunikasi, didapatkan nilai Cronbach's Alpha sebesar 0,647 yang berarti butir-butir iklim komunikasi organisasi tersebut reliabel karena memiliki Cronbach's Alpha > 0,6.

Tabel 5. Reliabilitas Variabel Kinerja Pegawai

\begin{tabular}{ll}
\hline Cronbach's Alpha & N of Items \\
\hline 786 & 13
\end{tabular}

Sumber: Pengolahan Data SPSS Versi 25.0

Dari pengujian reliabilitas terhadap 13 butir variabel kinerja pegawai, didapatkan nilai Cronbach's Alpha sebesar 0,786 yang berarti butir-butir kinerja pegawai tersebut reliabel karena memiliki Cronbach's Alpha >0,6. 
Uji Normalitas

Gambar 2. Diagram Sumbu Diagonal Uji Normalitas

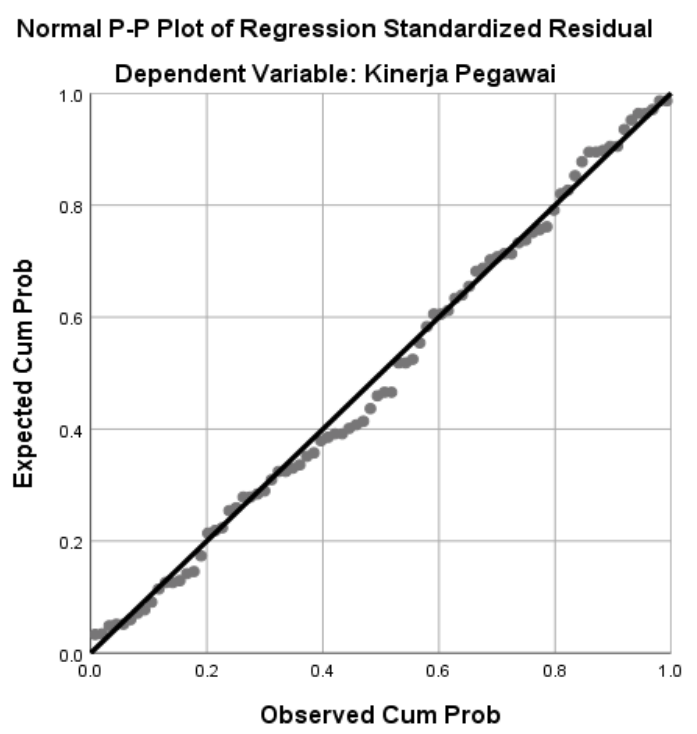

Sumber: Pengolahan Data SPSS Versi 25.0

Gambar tersebut menunjukkan data yang menyebar di sekitar garis diagonal dengan arah hubungan koefisien positif dan mengikuti arah garis diagonal, maka model regresi dengan variabel terikat Kinerja Pegawai telah memenuhi uji normalitas.

Uji T

Tabel 6. Hasil Uji T Coefficients ${ }^{\mathrm{a}}$

\begin{tabular}{llccccc}
\hline \multirow{2}{*}{ Model } & \multicolumn{2}{c}{ Unstandardized Coefficients } & $\begin{array}{c}\text { Standardized } \\
\text { Coefficients }\end{array}$ & \multirow{2}{*}{ t } & Sig. \\
\cline { 2 - 5 } & & $\mathrm{B}$ & Std. Error & Beta & & \\
\hline \multirow{2}{*}{1} & (Constant) & 17.679 & 4.817 & & 3.670 & .000 \\
\cline { 2 - 7 } & Iklim Komunikasi & .736 & .111 & .596 & 6.646 & .000 \\
\hline
\end{tabular}

a. Dependent Variable: Kinerja Pegawai

Sumber: Pengolahan Data SPSS Versi 25.0

Uji T dapat dilakukan dengan pembuktian sebagai berikut:

1) $\mathrm{H}_{\mathrm{o}}$ : Sig $>\alpha$, tidak ada pengaruh iklim komunikasi organisasi (X) terhadap kinerja pegawai $(\mathrm{Y})$.

2) $\mathrm{H}_{\mathrm{a}}$ : Sig $<\alpha$, terdapat pengaruh iklim komunikasi organisasi (X) terhadap kinerja pegawai $(\mathrm{Y})$.

Berdasarkan hasil analisis data diketahui bahwa tingkat signifikasi $=0,000<$ 0,05. Karena nilai $\mathrm{p}<0,05$, maka $\mathrm{H}_{\mathrm{o}}$ ditolak dan $\mathrm{H}_{\mathrm{a}}$ diterima, yang berarti terdapat pengaruh positif iklim komunikasi organisasi terhadap kinerja pegawai. 
Uji Regresi Linear Sederhana

Tabel 7. Hasil Uji Regresi Linear Sederhana Coefficients ${ }^{\mathrm{a}}$

\begin{tabular}{ccccccc}
\hline \multirow{2}{*}{ Model } & \multicolumn{2}{c}{ Unstandardized Coefficients } & \multicolumn{2}{c}{$\begin{array}{c}\text { Standardized } \\
\text { Coefficients }\end{array}$} & \multirow{2}{*}{ t } & Sig. \\
\cline { 2 - 5 } & $\mathrm{B}$ & Std. Error & Beta & & \\
\hline 1 & (Constant) & 17.679 & 4.817 & & 3.670 & .000 \\
\cline { 2 - 6 } & $\begin{array}{c}\text { Iklim Komunikasi } \\
\text { Organisasi }\end{array}$ & .736 & .111 & .596 & 6.646 & .000 \\
\hline
\end{tabular}

a. Dependent Variable: Kinerja Pegawai

Sumber: Pengolahan Data SPSS Versi 25.0

$$
\begin{aligned}
& Y=a+b X \\
& Y=17,679+0,736 X
\end{aligned}
$$

Dengan keterangan $\mathrm{Y}=$ Kinerja Pegawai dan $\mathrm{X}=$ Iklim Komunikasi Organisasi Berdasarkan persamaan regresi linear di atas, dapat diuraikan sebagai berikut:

a. Nilai Y (Kinerja Pegawai) akan tetap sebesar 17,679 konstanta jika nilai X (Iklim Komunikasi Organisasi) tidak mengalami perubahan.

b. Jika nilai X (Iklim Komunikasi Organisasi) mengalami peningkatan sebesar 1 satuan, maka nilai Y (Kinerja Pegawai) akan mengalami peningkatan sebesar 0,736 menjadi 18,415 .

Koefisien Korelasi

Tabel 8. Hasil Uji Koefisien Korelasi Model Summary

\begin{tabular}{lllll}
\hline Model & R & R Square & Adjusted R Square & Std. Error of the Estimate \\
\hline 1 & $.596^{\mathrm{a}}$ & .356 & .348 & 3.57836 \\
\hline
\end{tabular}

a. Predictors: (Constant), Iklim Komunikasi Organisasi

Sumber: Pengolahan Data SPSS Versi 25.0

Dari hasil perhitungan di atas, diketahui bahwa nilai koefisien korelasi (R) sebesar 0,596 yang berada di antara interval 0,40 - 0,599 artinya iklim komunikasi organisasi memiliki hubungan yang sedang dengan kinerja pegawai Ernst \& Young Indonesia divisi assurance sub-divisi $R C P$.

Koefisien Determinasi

Tabel 9. Hasil Uji Koefisien Determinasi Model Summary

\begin{tabular}{lllll}
\hline Model & $\mathrm{R}$ & $\mathrm{R}$ Square & Adjusted R Square & Std. Error of the Estimate \\
\hline 1 & $.596^{\mathrm{a}}$ & .356 & .348 & 3.57836 \\
\hline a. Predictors: (Constant), Iklim Komunikasi Organisasi & \\
Sumber: Pengolahan Data SPSS Versi 25.0
\end{tabular}

Dari hasil perhitungan di atas, diketahui bahwa nilai koefisien determinasi adalah sebesar 0,356 dimana 35,6\% kinerja pegawai dipengaruhi oleh iklim komunikasi organisasi sementara sisanya $64,4 \%$ dipengaruhi oleh faktor lain. 


\section{Simpulan}

Berdasarkan hasil penelitian yang telah penulis dapat disimpulkan bahwa: (1) Terdapat pengaruh antara Iklim Komunikasi Organisasi terhadap Kinerja Pegawai Ernst \& Young Indonesia divisi Assurance sub-divisi Retail and Consumer Product, (2) Pengajuan hipotesis ditemukan hasil perhitungan $\mathrm{H}_{o}$ ditolak sedangkan $\mathrm{H}_{\mathrm{a}}$ diterima, yaitu terdapat pengaruh yang terjadi antara kedua variabel. Pengaruh yang terjadi juga menunjukkan pengaruh yang signifikan dengan jumlah tingkat signifikasi $=0,000<$ 0,05 , (3) Hipotesis yang didapatkan peneliti dapat dibuktikan berdasarkan penelitian uji korelasi yang telah dilakukan sebelumnya, yaitu hasil angka korelasi Pearson 0,596, yaitu berkisar antara 0,40 - 0,599 yang menunjukkan bahwa Iklim Komunikasi Organisasi memiliki hubungan yang sedang dengan Kinerja Pegawai di Ernst \& Young Indonesia divisi Assurance sub-divisi $R C P$, dan (4) Iklim komunikasi organisasi 35,6\% mempengaruhi kinerja pegawai. Sedangkan sisanya, yaitu sebesar $64,4 \%$ dipengaruhi oleh faktor-faktor lain.

\section{Ucapan Terima Kasih}

Penulis menyadari bahwa penelitian ini tidak akan selesai tanpa bantuan berbagai pihak. Oleh karena itu, penulis mengucapkan banyak terima kasih kepada Bapak Daniel Tamburian, S.Sos., M.Si., Fakultas Ilmu Komunikasi Universitas Tarumangara, para responden, serta pihak lainnya yang telah membantu penelitian ini.

\section{Daftar Pustaka}

Bungin, Burhan. (2005). Metode Penelitian Kuantitatif: Komunikasi, Ekonomi, dan Kebijakan Publik Serta Ilmu-Ilmu Sosial Lainnya. Jakarta: Kencana.

Duha, Timotius. (2016). Perilaku Organisasi. Yogyakarta: Deepublish.

Fauzi, A., \& Sarwoprasodjo, S. (2015). Influencing of Organizational Climate Communication to Job Performance in Situ Udik Rural Government. Sodality: Jurnal Sosiologi Pedesaan, 2(3).

Irawan, D., \& Venus, A. (2016). Pengaruh Iklim Komunikasi Organisasi Terhadap Kinerja Pegawai Kantor Keluarga Berencana Jakarta Barat. Jurnal Kajian Komunikasi, 4(2), 122-132.

Pace, Wayne., Don F. Faules. (2015). Komunikasi Organisasi Strategi Meningkatkan Kinerja Perusahaan. Bandung: Remaja Rosdakarya.

Pendapatan "The Big Four” Masih Tertinggi. (2015, April 27). Retrivied September 10, 2018 from ppk online: http://www.pppk.kemenkeu.go.id/News/Details/18

Ruben, Brent D., Stewart, Lea P. (2013). Komunikasi dan Perilaku Manusia. Jakarta: Rajawali Pers.

Sugiyono. (2011). Metode Penelitian Pendidikan (Pendekatan Kuantitatif, Kualitatif, dan $R \& D)$. Bandung: Alfabeta. 